\title{
Notes on the vocalizations of Collared Antshrike (Sakesphorus bernardi)
}

Peter Boesman

In the following we briefly analyze and compare voice of the two races of Collared Antshrike (Sakesphorus bernardi). We also try to quantify the extent of any vocal differences using the criteria proposed by Tobias et al. (2010), as a support for taxonomic review.

We have made use of sound recordings available on-line from Xeno Canto (XC).

Loudsong of race shumbae from the Rio Marañon drainage is known to differ from 'coastal' birds (Schulenberg et al. 2007), mainly by its much faster song (Fig. 1).
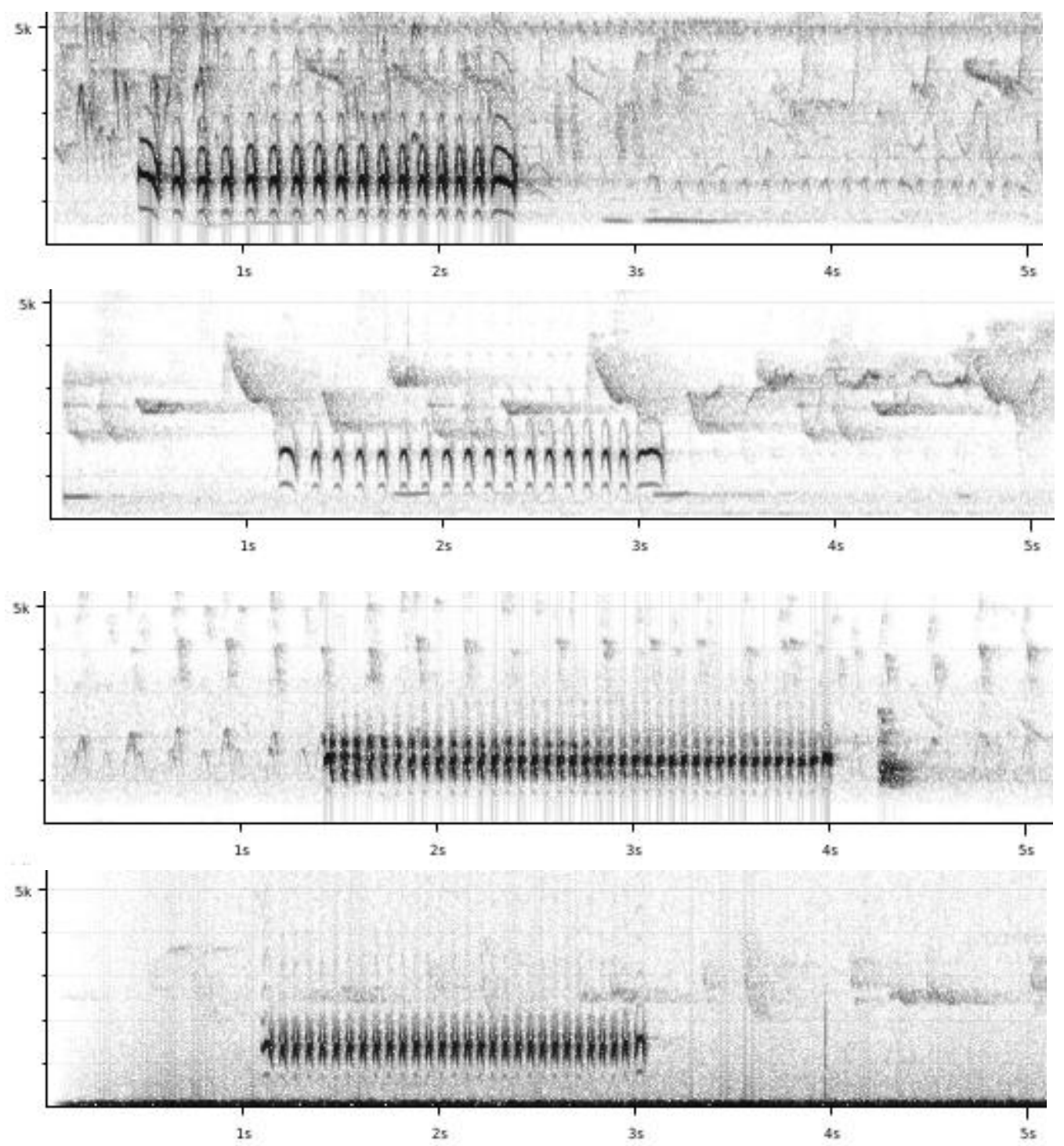

Figure 1: top to bottom: race bernardi (2 examples) and race shumbae (2 examples) 

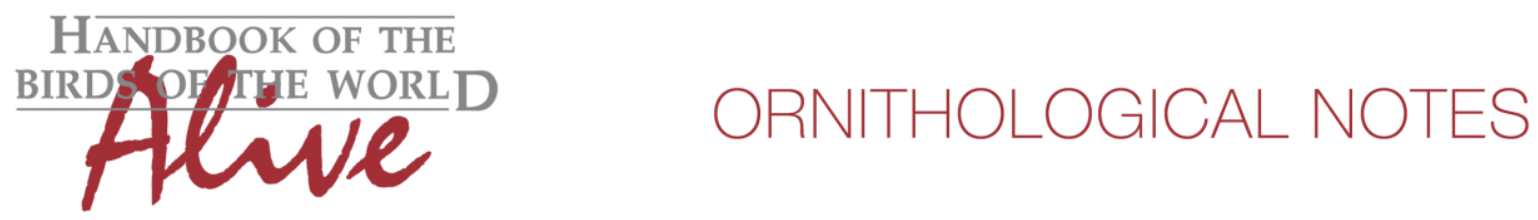

We have measured a few basic sound parameters in order to quantify this difference in loudsong:

bernardi $(n=8)$ : Song is a stuttering series of nasal caws with a longer first and last note. Series accelerates towards the end.

note length $0.049-0.062 \mathrm{~s} \quad$ (but down to $0.038 \mathrm{~s}$ in a recording of duet)

pace $\quad 8.5-10.5$ notes $/ \mathrm{s} \quad$ (but up to $11.8 \mathrm{n} / \mathrm{s}$ in a recording of duet)

shumbae $(n=4)$ : Song is a rattling series of nasal caws with a longer first and last note. Series accelerates towards the end. Structurally similar to bernardi, with similar note shape and frequency range, but notably faster.

note length $\quad 0.031-0.037 \mathrm{~s}$

pace $\quad 14.7-15.9$ notes/s

We can thus conclude that shumbae has a loudsong which is delivered much faster (score 23) and which consists of much shorter notes (score 2-3).

If we include the somewhat faster songs of bernardi when singing in duet, effect size drops somewhat. Nevertheless, difference still allows for a score of $2+2=4$

This note was finalized on 30th April 2015, using sound recordings available on-line at that moment. We would like to thank in particular the many sound recordists who placed their recordings for this species on XC.

\section{References}

Schulenberg, T.S., Stotz, D.F., Lane D.F., O'Neill J.P. \& Parker III, T.A. (2007). Birds of Peru. Princeton University Press. Princeton and Oxford.

Tobias, J.A., Seddon, N., Spottiswoode, C.N., Pilgrim, J.D., Fishpool, L.D.C. \& Collar, N.J. (2010). Quantitative criteria for species delimitation. Ibis 152(4): 724-746.

\section{Recommended citation}

Boesman, P. (2016). Notes on the vocalizations of Collared Antshrike (Sakesphorus bernardi). HBW Alive Ornithological Note 54. In: Handbook of the Birds of the World Alive. Lynx Edicions, Barcelona. (retrieved from http://www.hbw.com/node/931933 on 30 April 2016). 